\title{
The Influence of Service Quality and Location on Consumer Decisions at Hotel Vista in Prabumulih
}

\author{
Yudi Tusri ${ }^{1^{*}}$ \\ Prabumulih College of Economics ${ }^{1 *}$ \\ Corresponding Author: yuditusri72@gmail.com ${ }^{1^{*}}$
}

Keywords : Service Quality, Location, Consumer Decision

\begin{abstract}
:
This study shows that when testing the quality of service all the questions in the questionnaire are said to be valid with the provisions exceeding the value of $r$ table where the value of $r$ table is 0.185 . And for the reliability value obtained a value of 0.849 with the provisions above 0.185 it can be said that the existing questionnaire is declared reliable for further testing. At the time of testing the location, all the questions in the questionnaire were said to be valid with the provisions exceeding the value of $r$ table where the value of $r$ table was 0.185 . And for the reliability value obtained a value of 0.853 with the provisions above 0.185 it can be said that the existing questionnaire is declared reliable for further testing. For the calculated $f$ value of 33,505 and for the $f$ table value from the results of $n-k-1$ ( $n=$ respondent, $k=i n d e p e n d e n t$ variable) of 2.76. Thus, for the calculated $f$ value of 33,505 > the $f$ table value of 2.76, the service quality and location variables have a positive effect on consumer decisions.
\end{abstract}




\section{Introduction}

Hotel Vista is a hotel that is the most visited lodging place for tourists. The location of Hotel Vista is very strategic, located in the city center and not far from shopping centers. Currently, the development of hotel business competition in Prabumulih City is quite rapid. In terms of demographics, the location of the Prabumulih City area which is a crossing route between cities and cross-provincial routes, as well as the icon of Prabumulih City as a trade and business city is one of the interesting phenomena for us to study, especially with globalization in the economic field which is increasingly opening up opportunities for entrepreneurs. to attract consumers.

Realizing the rapid development of hotels in Prabumulih City, hoteliers are increasingly required to recognize consumer behavior and then adjust the company's capabilities to consumer needs. The added value offered by hotel companies is increasingly providing stability to potential customers to transact or encouraging old customers to transact.

Various strategies and methods are carried out by hotel companies to attract customers, one of which is how the hotel can attract customers and retain them by providing the best quality service so that consumers are satisfied with the services provided by the hotel. With a variety of attractive promos and discounts, it is hoped that customers will continue to increase. But on the other hand, competition in the field of hospitality companies is getting more and more competitive with prospective customers more easily accessing price quotes and facilities offered with online applications such as Traveloka and similar applications that can be easily accessed via the internet. So that potential customers have a variety of choices to fulfill their wishes.

The problem behind this research is the quality of service and location. The company carries out various strategies to be able to provide satisfaction to customers, thus leading to loyalty to the company. The hotel company that wins the competition is the one that is able to provide satisfaction to its customers, so that the company can continue to increase profits. The following data has been obtained regarding the number of guests staying at Hotel Vista Kota Prabumulih in the last 3 years

Table 1. Number of Hotel Visitors 2017-2019 period

\begin{tabular}{ll}
\hline Year & Numbers \\
\hline 2017 & 1.657 visitors \\
2018 & 1.815 visitors \\
2019 & 2.134 visitors \\
\hline
\end{tabular}

Source : Hotel Vista

Based on the table above, it can be seen that there is a fluctuation in the number of guests staying at the hotel. During the 2017-2019 period, the number of guests staying tended to increase. The hotel has set a minimum target occupancy rate in 2019 which is 2000 guests or on average there are about 5 to 6 guests checking in per day, in fact the number of guests in 2019 only reached 2,134 which means in accordance with the targets set by the hotel. 
Consumers in this case are heterogeneous communities that come from various backgrounds, characteristics, habits, regions, cultures, and economic levels. With the background of several theories, previous research and the phenomenon of the problem, a study was conducted to analyze the influence of service quality, and location on consumer decisions to stay at Hotel Vista Prabumulih. According to Payne (2012:10) service marketing is the process of perceiving, understanding, stimulating and meeting the needs of a specially selected target market by channeling an organization's resources to meet those needs.

Based on some of the descriptions above, this research was conducted to determine the factors that influence someone to stay at the hotel. In this study, the variables of service quality, and location were chosen as the focus of the research. The study focused on these two variables because it is suspected that these variables have a significant influence on consumer decisions to stay at Hotel Vista.

\section{Research Method}

The type of research used in this study is quantitative research, meaning that in analyzing data using numbers formulas or mathematical models (Singarimbun (2011:5). The reason for using this research is to get the expected results. In this study, a hypothesis was used which related to the analysis under study, accompanied by data collection techniques used, namely questionnaires, interviews, and literature studies.

The descriptive method according to Subiyanto (2017:12) is a method that is carried out by examining in depth an object of research that is selected from several conditions that are considered the same and is research that takes a picture of the situation as it is, as detailed as possible and complete, then analyzed and concluded as a depiction of a The situation taken should not be generalized with the overall conclusion being considered the same.

The design of this research begins with a quantitative problem and limits the problems in the problem formulation. The formulation of the problem is stated in the question sentence, then the researcher uses the theory to answer it. Sugiyono (2015:23) states that "Research designs must be specific, clear and detailed, determined steadily from the start, being a step by step guide". According to Sugiyono (2015: 117), which is a generalization area consisting of objects or subjects that have certain qualities and characteristics determined by researchers so that they can be studied and then drawn conclusions. The population in this study were 80 visitors to Hotel Vista Prabumulih.

According to Sugiyono (2015: 96), sampling in this study is to use the Accidental Sampling Method, which is a random sampling technique (whenever and wherever found) as long as it meets the requirements as a sample from a certain population. The determination of the research area was carried out purposively at the Vista Hotel in Prabumulih City. Determination of the sample from a population of 80 people who stay at the hotel. The sampling method was carried out by the Saturated Sampling method, because the population was less than 100 people. 
The instrument used in this study is intended to produce accurate data by using a Likert scale. According to Sugiyono (2015:134) "it is used to measure an attitude, opinion and perception of a person or group of people about a social phenomenon". In this study, the researcher used the type of questionnaire or questionnaire instrument with the following scoring:

Interviews are data collection by holding questions and answers with respondents, namely with a list of questions to be filled with information by respondents during the interview process. Questionnaire or list of questions is a data collection technique that is carried out by compiling closed and open questions with the answers provided, and must be filled out by respondents by choosing one of the available alternative answers and their reasons. It is a collection of data with the aim of finding out various knowledge or theories related to research problems, including those from books, magazines, journals or various literature relevant to the research.

The coefficient of determination shows how well the regression line estimate is able to accurately describe the actual regression line (goodness of fit). R2 is also able to show the percentage of variation in the dependent variable that can be explained by variations in the independent variable. The R2 test is intended to measure the ability to measure the percentage of variation in the independent variable (independent) in a simple linear regression model in explaining the variation in the dependent variable, Priyatno (201:142). In other words, testing the model using R2, can show that the independent variables used in the simple linear regression model are independent variables that are able to represent the whole of the other independent variables in influencing the dependent variable, then the magnitude of the effect is shown in the form of a percentage.

\section{Result and Discussion}

Normality test

Normality test must be done with independent variable data to determine whether the population data is normally distributed or not. Testing this requirement is done by using the normality detection test. It is done by looking at the normal probability plot graph from the SPSS program, normality.

1. If the data spreads around the diagonal line and follows the direction of the diagonal line, the regression model meets normality.

2. If the data spreads far from the diagonal and or does not follow the direction of the diagonal line, the regression model does not meet normality.

Normal P-P Plot of Regression Standardized Residual

Dependent Variable: Service quality and location on the decision to stay 


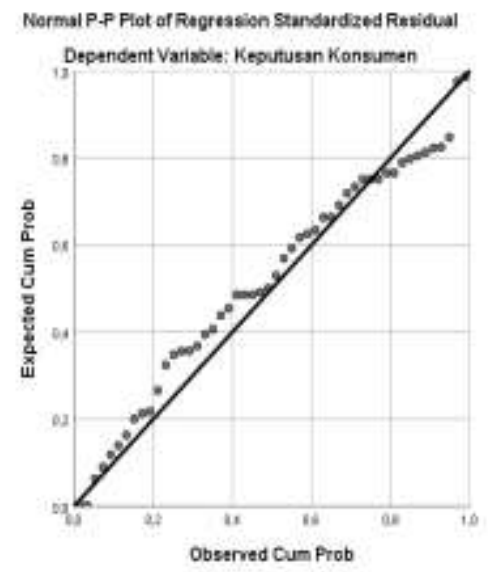

Figure 1. Normality test

In figure 1, it can be seen that the Normal Plot of dots is shown, so the regression model meets normality because the data spreads around the diagonal line and follows the direction of the diagonal line.

\section{Heteroscedasticity Test}

After testing for normality, the next step is Heteroscedasticity. Heteroscedasticity testing aims to determine whether in the regression model there is an inequality of variance from the residuals of other observable observations with the basis for making decisions as follows:

- If there is data that forms a certain pattern, such as points that form a certain and regular pattern (wavy, widen and then narrows), then Heteroscedasticity has occurred.

- If there are no clear points and the points are spread above and below the number zero on the $\mathrm{Y}$ axis, then there is no heteroscedasticity.

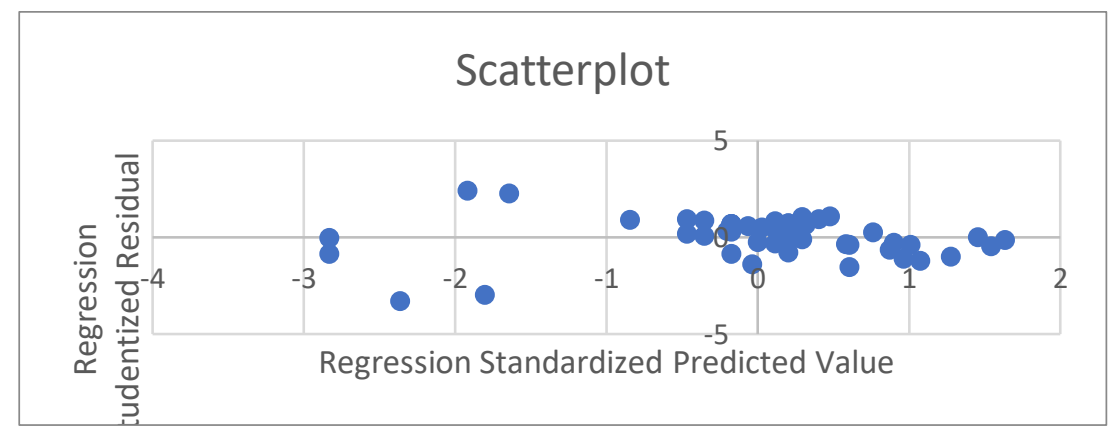

Figure 2. Heteroscedasticity Test Results

Multicollinearity Test

After the Normality and Heteroscedasticity Test, a Multicollinearity test will be carried out. To see if there is multicollinearity, it can be explained from the high $\mathrm{R}$ square value but the variable is not significant. In the calculation results, the value of $\mathrm{R}$ square $=0$. 
Hypothesis testing

Data analysis was performed using multiple linear regression in order to determine the effect of service quality and location on the decision to stay. The Statistical Package for Social Science (SPSS) will be used to assist the process of multiple linear analysis. Hypothesis testing is done to test the hypothesis that has been made and see how much influence the quality of service, facilities, and location have on the decision to stay. Hypothesis testing is done by testing the effect of each variable on loyalty

t test

The t-test basically shows how far the influence of one independent variable individually or partially in explaining the variation of the dependent variable. This decision is made based on the comparison of the significance value of the tcount value of each regression coefficient with a predetermined significance level, which is $5 \%(0.05)$, if the tcount significance is greater than 0.05 then the null hypothesis ( $\mathrm{Ho}$ ) is accepted. meaning that the variable has no effect on the dependent variable. If the significance of tcount is less than 0.05 , then ( $\mathrm{Ho}$ ) is rejected, which means that the independent variable affects the dependent variable. The explanation for the results of the t-test on each independent variable is as follows:

Table 2 .t Test

Coefficients $^{a}$

\begin{tabular}{|c|c|c|c|c|c|c|}
\hline \multicolumn{2}{|c|}{ Model } & \multicolumn{2}{|c|}{$\begin{array}{l}\text { Unstandardized } \\
\text { Coefficients }\end{array}$} & \multirow{2}{*}{$\begin{array}{c}\text { Standa } \\
\text { rdized } \\
\text { Coeffic } \\
\text { ients } \\
\text { Beta }\end{array}$} & \multirow[t]{2}{*}{$t$} & \multirow[t]{2}{*}{ Sig. } \\
\hline & & B & $\begin{array}{l}\text { Std. } \\
\text { Error }\end{array}$ & & & \\
\hline \multirow[t]{3}{*}{1} & (Constant) & 23,915 & 11,139 & & 2,147 & ,035 \\
\hline & $\begin{array}{l}\text { Kualitas } \\
\text { Pelayanan }\end{array}$ & ,663 & ,088 & 687 & 7,528 & ,000 \\
\hline & Lokasi & ,012 & ,089 & ,412 & 5,134 & ,894 \\
\hline
\end{tabular}

a. Dependent Variable: Consumer decision

Source: Primary data processed with SPSS 26.0, 2021

$\mathrm{H}_{0}: \mathrm{bi}=0$, there is no effect between the independent variable and the dependent variable $\mathrm{H}_{1}$ : $\mathrm{bi}>0$, the independent variable affects the dependent variable.

The results of the t-test analysis are as follows:

a. From the table above, we can see that the Service Quality variable (X1) has a value of tcount (7.528) $>$ ttable (1.668) with a significant value of $0.000<0.05$, so it can affect Consumer Decisions ( $\mathrm{Y}$ ) and means that $\mathrm{H} 1$ is accepted.

b. From the table above, we can see that the location variable $(\mathrm{X} 2)$ has a value of tcount (5.134) > ttable (1.668) with a significant value of $0.000<0.05$, so it can affect Consumer 
Decisions ( $\mathrm{Y}$ ) and means that $\mathrm{H} 2 \mathrm{p}$ is accepted.

F Test (Simultaneous Test)

The $\mathrm{F}$ test is used to test whether the independent variables simultaneously have a significant effect on the dependent variable. Where $\mathrm{F}$ count $>\mathrm{F}$ table, then the hypothesis is accepted or together the independent variables can explain the dependent variable simultaneously. On the contrary, if $\mathrm{F}$ count < F table, then $\mathrm{HO}$ is accepted or jointly the independent variables have no effect on the dependent variable.

To find out whether or not the influence of the independent variables together on the dependent variable is significant, a probability of $5 \%(\alpha=0.005)$ is used.

Table 3. F test

ANOVA $^{a}$

\begin{tabular}{llcrccc}
\hline Model & & $\begin{array}{c}\text { Sum of } \\
\text { Squares }\end{array}$ & df & $\begin{array}{c}\text { Mean } \\
\text { Square }\end{array}$ & F & Sig. \\
\hline 1 & Regression & 1070.937 & 2 & 535.469 & 33.505 &, $000^{b}$ \\
& Residual & 1230.613 & 77 & 15.982 & & \\
& Total & 2301.550 & 79 & & &
\end{tabular}

a. Dependent Variable: Consumer Decision

b. Predictors: (Constant), Location, Service Quality

Source: Primary data processed with SPSS 26.0, 2021

Based on the ANOVA test or $f$ test from the SPSS output, it can be seen that fcount $(33,505)$ $>$ ftable $(2,76)$ with a significant value of $0.000<0.05$, the Independent Variable has a positive and significant effect on the Dependent Variable.

\section{Coefficient of Determination}

The coefficient of determination is used to detect how far the relationship and the ability of the model to explain the dependent variation. In the processed data, there are three independent variables. As in the following table:

Table 4. Coefficient of Determination table

\begin{tabular}{lcccc}
\hline Model & $\mathrm{R}$ & $\begin{array}{c}\text { Model Summary } \\
\mathrm{R}\end{array}$ & $\begin{array}{c}\text { Adjusted R } \\
\text { Square }\end{array}$ & $\begin{array}{c}\text { Std. Error of } \\
\text { the Estimate }\end{array}$ \\
\hline 1 &, $682^{\mathrm{a}}$ & 0.465 & 0.451 & 3.99775 \\
\multicolumn{4}{l}{ a. Predictors: (Constant), Location, Service Quality } \\
\hline \multicolumn{4}{l}{ Source: Primary data processed with SPSS 26.0, 2021 }
\end{tabular}

In the table above, it can be seen that the adjusted $\mathrm{R}^{2}$ test results in this study obtained an adjusted R2 value of 0.451 which means that the magnitude of the influence of service quality 
and location variables on consumer decisions is $45.1 \%$, while the remaining $54.9 \%$ is influenced by other factors. that are not included in research such as Facilities.

\section{Partial Effect of Service Quality on Consumer Decisions}

The Service Quality Variable (X1) is declared to have a positive influence on the Consumer Decision variable $(Y)$ where we can see that the Service Quality variable $(X 1)$ has a value of $t_{\text {count }}$ (7.528) $>t_{\text {table }}(1.668)$ with a significant value of $0.000<0.05$ then it can have an effect to Consumer Decisions $(\mathrm{Y})$. With the $\mathrm{X} 1$ Regression value of 0.678 . This means that if there is an increase of 1 (unit) in the Service Quality variable (X1), the Consumer Decision (Y) will increase by 0.687 .

\section{Partial Effect of Location on Consumer Decisions}

Location variable (X2) is declared to have a positive influence on the Consumer Decision variable $(Y)$ where we can see that the Location variable $(X 2)$ has a value of $t_{\text {hitung }}(5,134)>t_{\text {tabel }}$ $(1,668)$ with a significant value of $0.000<0.05$ then it can affect the decision Consumers $(Y)$. With the $X 2$ Regression value of 0.012 . This means that if there is an increase of 1 (unit) in the Location variable (X2), the Consumer Decision (Y) will increase by 0.012 .

The Effect of Simultaneous Service Quality and Location on Consumer Decisions

Service Quality (X1) and Location (X2) variables are declared to have a positive influence on the Consumer Decision variable $(Y)$ where we can see that the Service Quality (X1) and Location (X2) variables have a value of $f_{\text {hitung }}(33.505)>f_{\text {tabel }}(2,76)$ with a determination value of $0.000<0.05$, it can affect Consumer Decisions $(\mathrm{Y})$. With an Adjusted $\mathrm{R}$ Square value of 0.451 . This increases the contribution of the independent variable to the dependent variable by $45.1 \%$ and the remaining $54.9 \%$ is influenced by other variables such as facilities.

\section{Conclusion}

Based on the results of the study and the results of data analysis, several conclusions can be drawn as follows:

1. There is a partial influence that the Service Quality variable (X1) has a value of $t_{\text {hitung }}$ (7.528) $>t_{\text {table }}(1.668)$ with a significant value of $0.000<0.05$ so it can affect Consumer Decisions (Y).

2. There is a partial effect that the location variable $(X 2)$ has a value of thitung $(5.134)>$ $t_{\text {table }}(1.668)$ with a significant value of $0.000<0.05$ so it can affect Consumer Decisions (Y).

3. There is a simultaneous influence that the Service Quality (X1) and Location (X2) variables have a value of $f_{\text {hitung }}(33,505)>f_{\text {tabel }}(2.76)$ with a determination value of $0.000<0.05$ so it can affect Consumer Decisions $(\mathrm{Y})$.

\section{References}


Akhmad. 2017. Teori Peluang. Penerbit UM Purwokerto Press. Purwokerto

Assael. 2015. Consumer Behavior and Marketing Action (6th ed). Cincinnati, Ohio. South Wettern Collage.

Azwar. 2013. Sejarah Pemikiran Ekonomi. Penerbit PT Raja Grafindo Pesada. Jakarta.

Berry,L., Zeithaml,V., Parasuraman,A., (2018)'The Service-Quality Puzzle', Business Horizons

Bitner, M. J. dan Zeithaml, V. A., 2016, Service Marketing (3rd ed.), Tata McGraw Hill, New Delhi.

Echdar. 2015. Metode penelitian Manjemen dan Bisnis. PT Ghalia Indonesia. Bogor.

Ferdinand. 2016. Metode Penelitian Manajemen. Penerbit Universitas Diponegoro. Semarang.

Ghozali. 2013. Ekonomi Sufistik. Penerbit CV Alfabeta. Bndung.

Groonroos. 2013. Services Management and Marketing: A Customer, Relationship, Management Approach (2nd ed). Chichester: John wiley and Sons, Ltd.

Hasan. 2013. Ekonomi Teknik. Penerbit Graha Ilmu. Yogyakarta.

Heizer, Jay dan Barry Rander. 2016. Operations Management Buku2 edisi ke tujuh. Penerbit Salemba Empat, Jakarta.

Kotler dan Keller. 2019. Keputusan Konsumen. Penerbit Pustaka Pelajar. Jakarta.

Lupiyoadi, Rambat. 2011. Manajemen Pemasaran Jasa. Jakarta : PT. Salemba Empat.

Masud. 2015. Ekonomi Politik Internasional dan Pembangunan. Penerbit Pustaka Pelajar. Jakarta.

Murti dan Soeprihanto. 2012. Pengantar Bisnis (Dasar-dasar Ekonomi Perusahaan). Penerbit Liberty. Yogyakarta.

Orilio D. 2016. Marketing. New Jersey: Prentice Hall International Inc.

Pasuraman. 2014. The Behaviorial Consequenses of Services Quality. New Jersey: Prentince Hall.

Paul. 2013. Perilaku Konsumen. Penerbit Binarupa Aksara. Jakarta.

Payne. 2012. The Essence of Services Marketing (Pemasaran Jasa). Penerbit Andy. Yogyakarta.

Priyatno. 2012. Ekonomi Pemerintahan. Penerbit Universitas Terbuka. Tanggerang.

Ratminto. 2013. Manajemen Pelayanan. Penerbit Pustaka Pelajar. Jakarta.

Saleh. 2015. Ekonomi Konvensonal. Penerbit Universitas Asahan. Sumatera Utara.

Sambodo Agus \& Bagyono. 2016. Dasar-Dasar Kantor Depan Hotel. Cv. Andi offset. Yogyakarta.

Singarimbun. 2011. Metode Penelitian Survei. Penerbit LP3ES. Jakarta.

Subiyanto. 2017. Penerapan Matematika dalam Ekonomi. Penerbit STIA YKPN. Yogyakarta. 
Sugiyono. 2015. Metode Penelitian Kuantitatif, Kualitatif, dan R\&D. Penerbit CV Alfabeta. Bandung.

Sumaatmadja. 2013. Studi Geografi Suatu Pendekatan dan Analisa Keruangan. Penerbit Alumni. Bandung.

Sumarwan. 2013. Perilaku Konsumen: Teori dan Penerapannya. Penerbit PT Ghalia Indonesia. Bogor.

Swasta dan Irawan, 2013, Manajemen Pemasaran: Analisa dan Perilaku Konsumen. BPFE. Yogyakarta

Tjiptono, Fandy. 2013. Strategi Pemasaran. Penerbit Andy. Yogyakarta.

Umar. 2013. Fikih Ekonomi. Penerbit Pustaka Al-Kautsar. Jakarta.

Zeithaml, Parasuraman, Berry ,2016. "Delivering Quality Service”, New York : The Free Press (Lihat juga Subhash et al., International Journal Of Retail and Distribution Management). 